\title{
ABBREVIATIONS
}

\section{JÜRGEN HABERMAS}

BFN

BNR

CES

DEA

DS

EFP

FG

FHN

JA

JS

MCCA

MW

ND II
Between Facts and Norms: Contributions to a Discourse Theory of Law and Democracy (1996) Between Naturalism and Religion (2008) Communication and the Evolution of Society (1979) Die Einbeziehung des Anderen (1996) The Dialectics of Secularization: On Reason and Religion (2006)

Europe: The Faltering Project (2009)

Faktizität und Geltung (1992)

The Future of Human Nature (2003)

Justification and Application: Remarks on Discourse Ethics (1993)

"Justice and Solidarity: On the Discussion Concerning 'Stage 6'” (1989)

Moral Consciousness and Communicative Action (1990)

" 'Reasonable" Versus 'True, or the Morality of Worldviews" (1998)

Nachmetaphysiches Denken II: Aufsätze und Repliken (1988) 
PDM

PF

PMT

Reply 1

Reply 2

Reply 3

RPS

RPUR

$\mathrm{RR}$

RW

SE

TCA I

TCA II

TCC

TIO

TJ

VE

WR

ZNR
The Philosophical Discourse of Modernity: Twelve Lectures (1987)

The Past as Future (1994)

Postmetaphysical Thinking: Philosophical Essays (1992)

"Reply to Symposium Participants, Benjamin N. Cardozo School of Law" (1996)

"Reply to My Critics," in Habermas and Rawls:

Disputing the Political (2011)

"Reply to My Critics," in Habermas and Religion (2013)

"Religion in the Public Sphere" (2006)

"Reconciliation Through the Public Use of

Reason: Remarks on John Rawls's Political

Liberalism" (1995)

Religion and Rationality: Essays on Reason, God, and Modernity (2002)

"Richtigkeit vs. Wahrheit" (1998)

"Sprechakttheoretische Erläuterungen zum Begriff der kommunikativen Rationalität" (1996)

The Theory of Communicative Action, vol. 1 (1985)

The Theory of Communicative Action, vol. 2 (1985)

"Towards a Communication-Concept of

Rational Collective Will-Formation: A Thought-

Experiment" (1989)

The Inclusion of the Other: Studies in Political

Theory (1998)

Truth and Justification (2003)

Vorstudien und Ergänzungen zur Theorie des

kommunikativen Handelns (1984)

Wahrheit und Rechtfertigung (1999)

Zwischen Naturalismus und Religion (2005) 


$$
\text { JOHN RAWLS }
$$

CP

JFAR

$\mathrm{KC}$

IPRR

$\mathrm{PL}$

$\mathrm{RH}$

TJ

HR

HRDP

PRPS
Collected Papers (2001)

Justice as Fairness: A Restatement (2001)

"Kantian Constructivism in Moral Theory" (1980)

“The Idea of Public Reason Revisited" (2005

[1993])

Political Liberalism (2005)

"Political Liberalism: Reply to Habermas" (1995)

A Theory of Justice (1972)

\section{COLLECTIONS}

Habermas and Religion (2013)

Habermas and Rawls: Disputing the Political (2011)

The Power of Religion in the Public Sphere (2011) 

THE HABERMAS-RAWLS DEBATE 
